https://doi.org/10.18485/iipe_postsovjet.2021.ch19

Душан Пророковић ${ }^{1}$

\title{
ОДРЖАВАЊЕ СТАБИЛНОСТИ И ПРЕТЊЕ БЕЗБЕДНОСТИ: СЛУЧАЈ ТАЏИКИСТАНА
}

\begin{abstract}
Ancmракт: Грађански рат, који је трајао деведесетих година 20. века, дугорочно је одредио политичке процесе у Таџикистану. С једне стране, председник Емомали Рахмон, несумњиво најважнији актер у процесу стабилизације прилика током послератног периода, учврстио је своју власт и постао незаобилазан саговорник за све спољне чиниоце безбедности Централноазијског региона. С друге стране, ратна разарања и економска девастација оставиле су последице које се осећају и данас и које могу бити претња безбедности. Овај прегледни рад чине четири поглавља. Поред уводног и завршног закључног, друго поглавље посвећено је опису узрока и последица грађанског рата, а треће послератној стабилизацији и текућем стању. У раду се анализом садржаја и компаративном анализом представљају изазови стабилности и претње безбедности Таџикстана, као и однос САД, Русије и Кине према овом питању.

Кључне речи: Таџикистан, Рахмон, авганистански рат, грађански рат.
\end{abstract}

\section{Увод}

Практично од осамостаљивања 1991. године, Република Таџикистан суочена је са великим изазовима у одржавању елементарне стабилности.

\footnotetext{
${ }^{1}$ Институт за међународну политику и привреду, Београд, dusan@diplomacy.bg.ac.rs Рад је настао у оквиру научноистраживачког пројекта „Србија и изазови у међународним односима 2021. године“, који финансира Министарство просвете, науке и технолошког развоја Републике Србије, а реализује Институт за међународну политику и привреду током 2021. године.
} 
Чланство у ОДКБ (Организација уговора о колективној безбедности) још од 1992. и Шангајској организацији за сарадњу (ШОС) од 1996. године, свакако је помогло да се након грађанског рата успоставе институције, утврди позиција у међународним односима и захваљујући томе осигура регионална безбедност. Ипак, остали су актуелни бројни изазови, који јесу или могу бити претња не само унутрашњој (националној или државној) безбедности већ и у ширем регионалном контексту. Таџикистан се граничи са Кином и Авганистаном, део таџичке популације живи у ове две земље (у Авганистану су Таџици, након Паштуна, друга најбројнија популација, а таџичким дари језиком као првим говори највећи део авганистанске популације, скоро половина), што упућује на закључак да се свака криза може „прелити“ и ван граница матичне државе (исто као што су дешавања у Авганистану утицала на дестабилизацију унутар Таџикистана почетком деведесетих година 20. века), а континуалне напетости у односима са западним суседом Узбекистаном такође онеспокојавају (након бољшевичке револуције и нове просторне прекомпозиције Таџикситан најпре није био проглашен совјетском конститутивном републиком, то ће постати тек 1929. године, већ „само“ аутономном јединицом унутар Узбекистана од 1924, док су од 1920-1924. године делови државе били организовани као посебне јединице унутар Бухарске Народне Совјетске Републике). 
Карта бр. 1: Гармска област и унутрашња организација Таџикистанске ССР 1940. године

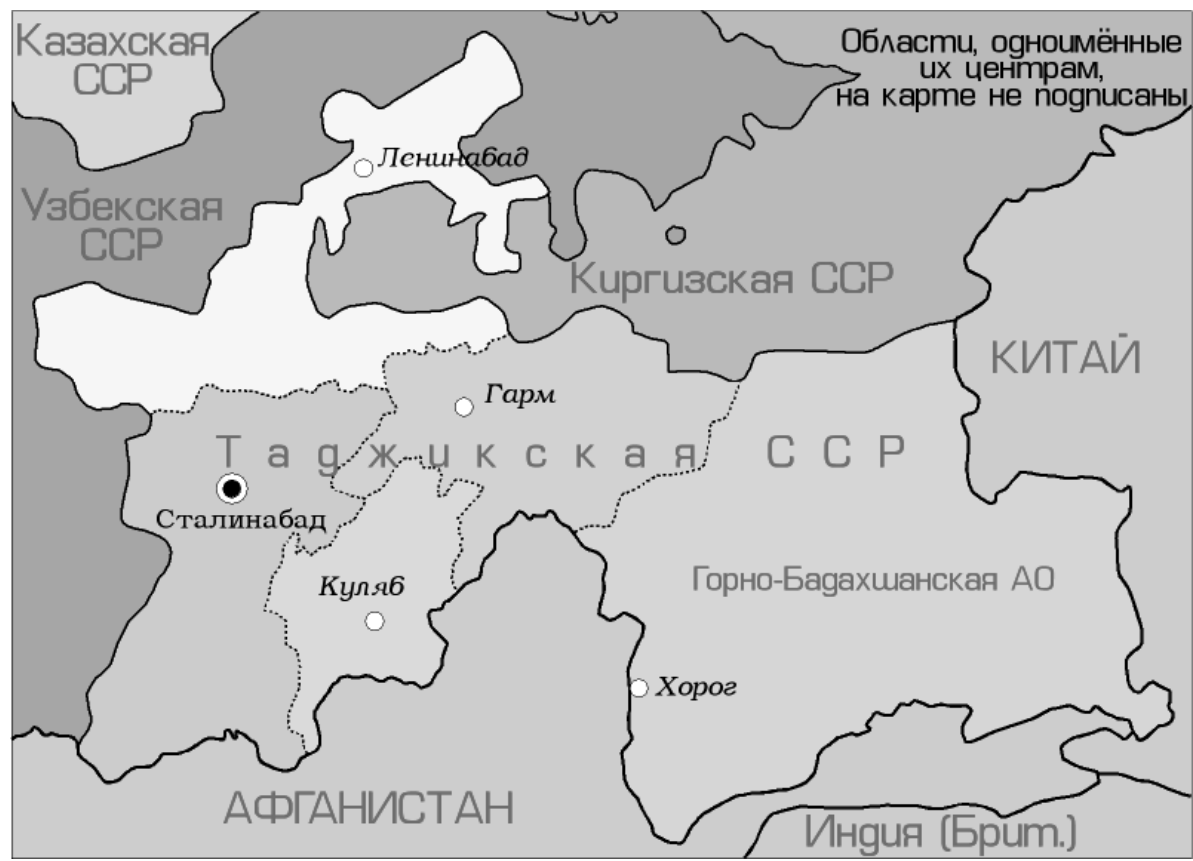

Специфичност позиције Таџикистана одређује и комплексно историјско наслеђе, које се нити може нити сме искључиво везивати за „изненадно“ стицање независности узроковано распадом Совјетског Савеза и релативном неспремношћу да се започне „нови циклус“ у државотворном процесу. Таџици су део шире иранске етничке заједнице, говоре језиком који је дијалект персијског, али су поред тога већином сунити (за разлику од иранских шиита), што их у погледу религијског, више

\footnotetext{
2 Карта преузета са интернет адресе која се наводи у фусноти. Према изјави аутора (доступна на линку који се наводи) карту је могуће користити и публиковати уз услов јасног и недвосмисленог навођења одакле потиче и без преправљања и било каквих дорада. Aymop: Geoalex - собственная работа, CC BY-SA 3.0; File: Карта Таджикской CCP -1940 г.png. Преузето са: https://commons. wikimedia.org/w/index.php?curid=27954686, приступљено 01.03.2021.
} 
сврстава уз арапске и монголске муслиманске народе. Културни и политички утицај Русије је релативно висок, везе грађене током трајања заједничке совјетске државе опстале су, упркос очигледном процесу делимичне дерусификације настале у фази десовјетизације политичког и друштвеног система, а као најзначајнији економски партнер у последњој деценији појављује се Кина, што са собом доноси и све интензивније кинеске политичке и културне импулсе.

Што се тиче односа са Русијом, неопходно је подвући и да ова земља представља најчешћу дестинацију више стотина хиљада емиграната из Таџикистана, што није без значаја са сагледавање шире слике. ${ }^{3}$ Поред тога, заинтересованост САД за стањем у Таџикистану траје још од деведесетих година, а логично, повећава се након почетка (још једног!) авганистанског рата 2001. године. У ширем, историјском и геополитичком контексту (атлантистичка таласократија коју „предводе“ Велика Британија и САД, насупрот руске евроазијске телурократије), ово није нови моменат, пошто се заинтересованост Велике Британије за контролом централноазијског ареала, чији је саставни део и територија коју насељавају Таџици, детектује током целог 19. века. Поред чланства у две поменуте „безбедносне организације“, Таџикистан је од 2002. године интегрисан у НАТО структуру Партнерство за мир, чиме је требало да се осигура институционализација даље војно-политичке сарадње са САД.

\section{Грађански рат: узроци и последице}

Грађански рат, започет маја 1992. године, а који ће трајати наредних пола деценије на дуги рок одредио је „политички пут“ којим ће се кретати Таџикистан. „Последице ратних дејстава биле су катастрофалне. Процењује се да је до 1997. погинуло до 100.000 људи, огроман број привредних и стамбених објеката је уништен, а наставак је могао да дестабилизује и околна подручја“. Између десетине и петине популације

\footnotetext{
${ }^{3}$ Marina Bakanova, Ravshan Sobirzoda et al., Tajikistan:A moderate Slowdown in Economic Growth Coupled with a Sharp Decline in Household Purchasing Power, Tajikistan Economic Update No. 2, World Bank Group, Washington D.C., 2015, p. 3.

${ }^{4}$ Душан Пророковић, Ера мултиполарности, Службени гласник, Београд, 2018, стр. 625.
} 
остало је „интерно расељено“. 5 "Савет безбедности је Резолуцијом 968 успоставио посматрачку мисију УНМОТ, 1994. године (UN Mission on Tajikistan). Стални проблеми у раду мисије, којој нису дозвољавани приступи жељеним локацијама и разне опструкције готово свих учесника у сукобу, утицали су на то да ентузијазам у СБ по овом питању опадне: после убиства из заседе четири припадника мисије недалеко од града Гарм, јула 1998. године, њен рад је до даљег суспендован. Испоставиће се да више никада неће бити обновљен. Иако мали по површини (око

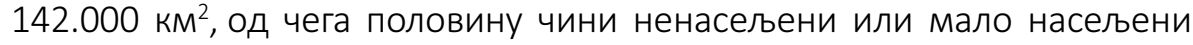
планински део Памира на истоку државе), Таџикистан заузима важан географски положај, јер се преко његове територије делимично протеже Ферганска долина - најплоднији и најгушће насељен део Средње Азије, јужном границом тече Сир-Дарја, а водотоком реке Вахша отворен је комуникацијски правац југозапад-североисток, од Авганистана до Киргизије. Таџикистан се граничи са Кином на истоку. Због тога је, и поред грађанског рата који се одвијао на четвртини територије земље, Таџикистан 1996. одмах укључен у Шангајску петорку, а још од 1992. је оснивач ОДКБ. Русија је улагала напоре мимо система УН да се ситуација смири. Кина је тај процес подржала." Док су западне земље, у првом реду САД као једина преостала суперсила у новом униполарном свету, средином деведесетих година 20. века биле фокусиране на источноевропско подручје, те мање пажње обраћале на централноазијски простор (што је укључивало и слабу заинтересованост за рад мисије УНМОТ и њен неславан завршетак након трагедије), за Русију и Кину то остаје значајна криза коју је неопходно решавати.

Узроци избијања сукоба су вишеслојни. Прво, то су етничке и историјске различитости. Иако су Таџици најбројнија популација, географска дистрибуција становништва указује да они не чине већину у југоисточном делу земље. Док западну, Хуџнадску област, у чијем центру је и главни град Душанбе, већински насељавају Таџици и Узбеци (са Русима, као мањином), значајан удео у југоисточном Горно Бадахшану су

\footnotetext{
${ }^{5}$ Bruce Pannier, “Tajikistan's Civil War: A Nightmare The Government Won't Let Its People Forget", Radio Free Europe, 23 June 2017, https://www.rferl.org/a/qishloq-ovozi-tajikistancivil-war/28575338.html (приступљено 25.02.2021).

${ }^{6}$ Душан Пророковић, Ера мултиполарности, ор. сіt., стр. 625-626.
} 
памирски народи. Они се сматрају потомцима старих народа који су живели на овим просторима (планинским областима). Поред тога, историјска Каратагена (у дословном преводу Црна Гора), као област са одређеним степеном самосталности, постојала је од античких времена, што је утицало на обликовање идентитетске различитиости (ову чињеницу нису могли занемарити ни совјетски комунисти, те је од 1929. па све до 1955. године постојала Гармијска аутономна област, са седиштем у граду Гарми, центру Каратагене). Важност овог питања видеће се још током трајања Совјетског Савеза, а послужити као основа почетком деведесетих за укорењивање сепаратистичких тенденција. Такође, важно је напоменути да се етничка структура мењала у корист Таџика, који су 1959. године чинили 53,1\% укупног становништва, а 1989. године већ 62,3\% (овакав тренд је настављен и након завршетка рата, па су Таџици 2002. чинили 79,9\%, а 2010. године 84,3\% укупне популације Таџикистана).

Карта бр. 2: Област Горно Бадахшана у Таџикистану

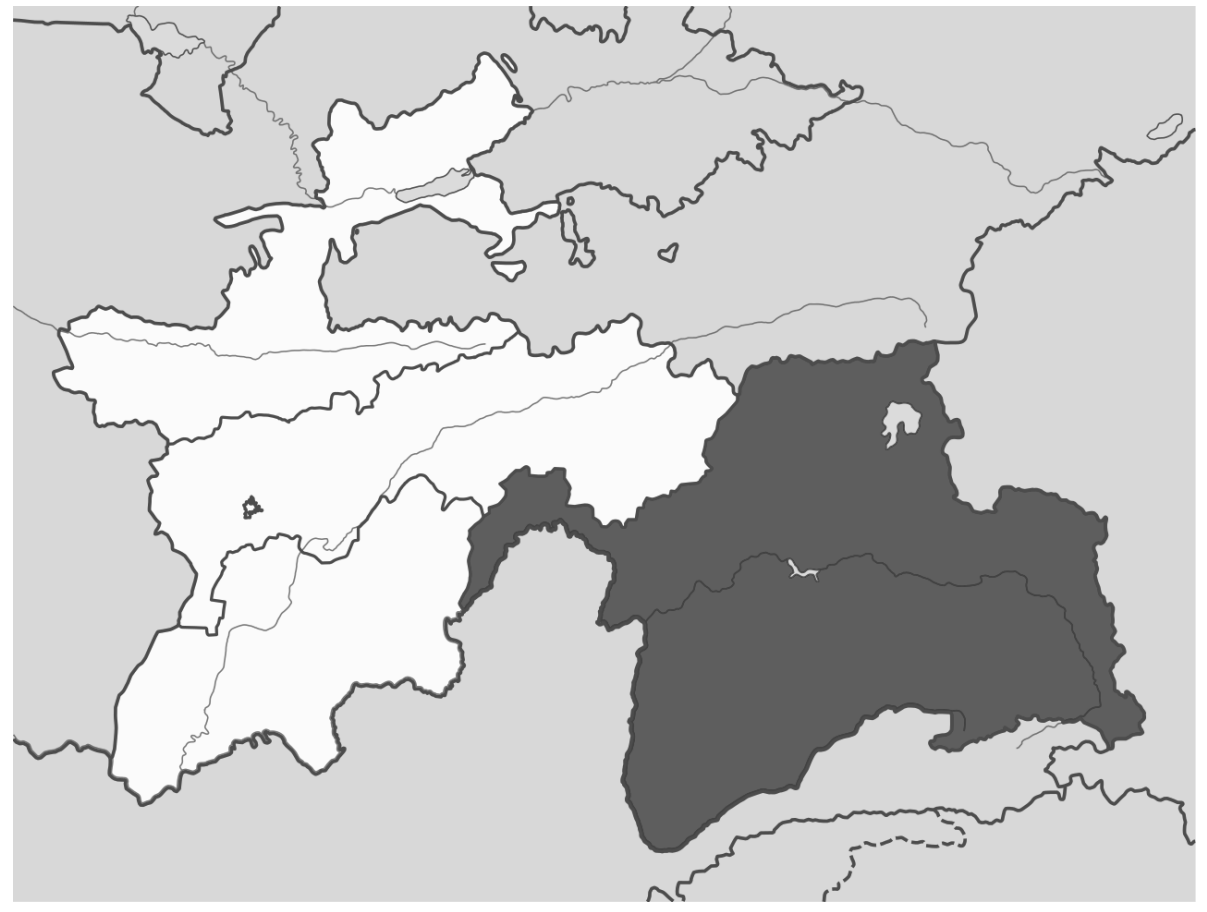


Друго, политичке тензије акумулиране су и због вођења кадровске политике унутар комунистичког система. У пракси је било готово немогуће да се Каратагинац нађе на било којој важној позицији у комунистичком систему, што се често наводи као разлог њиховом постепеном окретању ка исламу још седамдесетих година, што може, али и не мора бити тачан закључак. Ипак, јачање „исламског фактора“ у овој популацији детектује и тадашњи КГБ, али се покушај заустављања тог процеса завршио неуспехом и у пуном светлу открио почетком деведесетих. ${ }^{7}$ Насупрот елити у Душанбеу, коју контролишу комунистичке структуре, у Гармској области ниче исламска опозиција. Импулс обликовању ставова ове политичко-религијске групације дају идеолози муслиманских милиција које настају у узбекистанском делу Ферганске долине (1991-1995) и јачање талибанског покрета у Авганистану. ${ }^{8}$ "Сукоб је врло брзо прерастао у оружани, а исламској опозицији, у којој вероватно најважнију улогу има Сајид-Абдул Нури (Саид Абдулло Нури), придружују се скоро сви незадовољни влашћу председника Рахмона Набијева (Рахмон Набиевич Набиев). Тако се формира Јединствена таџичка опозиција (Объединённая таджсикская оппозиция), са својим паравојним јединицама. "9 Предуслови за почетак оружаног сукоба били су, дакле, испуњени.

Трећи разлог представља и уврежено мишљење о системском ускраћивању права на развој делу државе, које настаје као последица неравноправне расподеле економског богатства (инвестиције у инфраструктуру, индустријализација итд.). У совјетској планској економији Таџикистан је припадао Средњоазијском економском региону, заједно са Узбекистаном, Туркменијом и Киргизијом. Уз ташкентско, фрунзенско и самаркандско индустријско чвориште, још два важна представљају јужнотаџикистанско и фераганско-маргиланско која делимично или у потпуности

\footnotetext{
${ }^{7}$ О овоме више у: В. И. Бушков, Д. В. Микульский, Анатомия гражданской войны в Таджикистане (этно-социальные процессы и политическая борьба, 1992-1995), Институт этнологии и антропологии РАН: Институт практического востоковедения, Москва, 1996.

${ }^{8}$ Krzysztof Strachota, Maciej Falkowski, „Dżihad i Nowa Wielka Gra. Paradoksy zagrożenia wojującym islamem w Azji Centralnej", Ośrodek Studiów Wschodnich, Warszawa, 2010, p. 5.

${ }^{9}$ Душан Пророковић, Ера мултиполарности, ор. сіt., стр. 626.
} 
обухватају територију ове државе. У реформама осамдесетих година развијају се такозвани територијално-производни комплекси Совјетског Савеза, међу којима је јужно-таџикистански међу најкрупнијим. Индустријализација несумњиво доприноси развоју совјетске републике, акценат се ставља на обојену металургију и машиноградњу. Међутим, индустријализацијом су, пре свега, обухваћени западни делови земље, градови Душанбе, Јаван, Лењинабад (данашњи Хуџанд), Кајракум (данашњи Гулистон). ${ }^{10}$ Током времена, неравномерност у степену развијености међу западним (индустријализованим и урбанизованим) и источним (пољопривредним и руралним) делом земље постају све веће, што ствара како социјалне тако и политичке напетости. „Северозападни део земље, који обухвата Хуџандска (у доба комунизма Лењинабадска) област, са главним градом Душанбеом, развијенији је, насељенији, с бољим саобраћајницима и социјалном инфраструктуром. Током совјетских времена, 70-80\% свих инвестиција у индустрију, улагања у инфраструктуру и других подстицајних средстава завршавало је у овом делу државе. Географски ослоњен на Узбекистан, Душанбе је интензивирао сарадњу с Ташкентом и Самаркандом. Самим тим су такозвани северни кланови формирали партијску, политичку, економску и културну елиту земље. Источни део део земље - регион Горно Бадахшан - сиромашнији је, а његов јужни део географски је упућен на Авганистан. "11 У условима ескалације најпре политичког, а затим и оружаног сукобљавања, и ово постаје један од аргумената којим се објашњавају разлози сепарације периферије у односу на центар.

Табела бр. 1: Економски индикатори Таџикистана

\begin{tabular}{|l|c|c|}
\hline \multicolumn{1}{|c|}{ индикатор } & место у свету \\
\hline БДП (номинални) & 7.35 млрд УСД & 147 \\
\hline БДП (номинални) по становнику & 807 УСД & 164 \\
\hline БДП ППП & 30.547 млрд УСД & 132 \\
\hline БДП ППП по становнику & 3.354 УСД & 155 \\
\hline ХДИ & 0.668 & 125 \\
\hline
\end{tabular}

10 Према: Шукхрат Саъдиев, История таджикского народа, Институт предпринимательства и сервиса, Душанбе, 2012.

${ }^{11}$ Душан Пророковић, Ера мултиполарности, ор. сіt., стр. 625. 
Рат је оставио велике последице, како по унутрашње односе, тако и по економију државе. И пре распада Совјетског Савеза у економском погледу Таџикистан је заостајао за развијенијим деловима тада заједничке државе. Међутим, након рата, ова земља постаје једна од најсиромашнијих на свету. Уништавање инфраструктуре и индустријских капацитета, уз пратећи недостатак инвестиција, утицали су на „експлозију“ незапослености и миграције радно способног становништва (превасходно мушкараца, што је створило и феномен „остављања жена и деце“ утаџикистанским домаћинствима). Четврт века након суштинског завршетка сукоба и установљавања Комисије за национално помирење (Комиссия по национальному примирению) Таџикистан одликују изразита економска пасивност и заостајање чак и за земљама из ширег окружења (тешко је уопште упоређивати перформансе економског система са најразвијенијим државама) што је приказано у Табели бр. 1. ${ }^{12}$

\section{Послератна стабилизација и тренутно стање}

„Делимичној деескалацији помогла је промена на челу државе, 1994. године, када председник постаје Емомали Рахмон (Эмомали Рахмон). Организовано је неколико рунди преговора, а куриозитет представља што су у мају 1995. Рахмон и Нури договорили тромесечно примирје на састанку у Кабулу. Авганистан, који је шест година пре и шест година после тога постао поприште можда и најкрвавијих ратова виђених од 1945, у том тренутку је изабран за место мировних преговора зараћених страна из Таџикистана. Преговори су завршени потписивањем Московског протокола, 27. јуна 1997, и установљавањем Комисије за национално помирење, која је спроводила договорено до 2000. године.“13 Од 1992. године Рамонов је био на челу Врховног савета, а на позицији председника државе одржао се до данас, на изборима 2020. године убедљиво је победио,

12 Према: IMF, "World Economic Outlook Database", International Monetary Fund, 2019, https://www.imf.org/en/Publications/SPROLLs/world-economic-outlook-databases\#sort =\%40imfdate\%20descending (приступљено 27.02.2021)

${ }^{13}$ Душан Пророковић, Ера мултиполарности, ор. сіt., стр. 626. 
освојивши 92,08\% гласова у првом кругу гласања! У овом конкретном случају, испоставило се да учвршћивање власти (која се најпре могла описати као стабилократија, а након тога, у другој фази владавине и као аутократија) може допринети стабилизација прилика. Рахмон је успостављајући јасну хијерархијску структуру, издижући себе као председника изнад система и институција, врло брзо постао својеврсни „гарант“ у спровођењу договореног. У томе су му помогле још две ствари. Прво, једна од последица грађанског рата јесте и трауматизација друштва, уплашеног да се нешто слично не понови. Траума је и у годинама након окончања рата остала толико дубока, да су и опозиционе скупине (укључујући и најрадикалније, попут исламистичких политичких организација из југоисточних делова земље) биле приморане на ублажавање реторике којом би смирили тензије и избегле било какве провокације. Једноставно, било какво другачије постављање не би наишло на ширу подршку унутар друштва. У пракси је такав приступ значајно отупио оштрицу опозиционих напада на власт, што је Рахмон искористио да фактички или чак и формално угаси све опозиционе центре деловања (исламска партија коју је некада предводио већ споменути Нури забрањена је 2015. године уз образложење да подстиче верски фундаментализам). Не само да од Јединствене таџичке опозиције није остало ништа, већ чак ни од опозиције није остало ништа. Зато се као конкуренти на изборима појављују псеудоопозиционе партије или странке превазиђених идеологија са скромном подршком (Аграрна странка, Социјалистичка партија, Комунистичка партија) међу грађанима и без ширег утицаја неопходног за било какву врсту озбиљнијег угрожавања власти. „Игра престола“ одиграва се унутар владајуће структуре, што се манифестује повременим „искакањем“ неких важних министара или њихових заменика, чија популарност привремено нарасте, те траже већу улогу у систему власти. Последњи „драматичан догађај“ оваквог карактера забележен је 2015. године када се одметнуо заменик министра одбране Абдухалим Назарзода. Дотадашњи генерал смењен је са свих позиција 5. септембра због „почињених злочина“, а заједно са 135 присталица једанаест дана касније организовао је напад на полицијску станицу у граду Вахдат, двадесетак километара источно од престоног Душанбеа. У том сукобу погинуло је пет припадника таџикистанске полиције, а потера која је кренула стигла је Назарзоду сутрадан, када 
је и ликвидиран. ${ }^{14}$ И овом приликом, као и током процеса забране исламистичке партије (која једина има реалан потенцијал да угрози власт и окупи око себе значајнији број следбеника), занимљивост представља да није било већих манифестација исказивања незадовољства или снажнијих протеста унутар Таџикистана. Једно од образложења зашто је тако, може се тражити у (и даље!) уплашености од обнављања сукоба и новог грађанског рата (траума и даље оставља последице). У сваком случају, власти - ослањајући се на медије и континуалне пропагандне кампање - неуморно подсећају грађане на последице рата, стално „обнављају слику“ шта се може десити ако ескалирају политички сукоби, што им служи за учвршћивање позиције и наставак владавине Рахмона. „Да би се сећање на грађански рат одржало свежим, државна телевизија редовно емитује снимке сукоба. Државни религијски проповедници подржали су званични наратив, кривећи опозицију за рат. Медији под државном контролом приказали су Рахмона као јединог миротворца, заборављајући при томе да је сада преминули бивши шеф исламистичке партије, Саид Абдул Нури, такође имао кључну улогу у окончању рата. Једна од имплицитних порука јесте да политичка подела рађа нестабилност. Одговорност за грађански рат положена је у руке опозиционим групама које су оспоравале централну власт у периоду 1990-1992. Ово тумачење, које има широку резонанцу у таџикистанском друштву, ставља терет стабилности у Таџикистану на плећа недржавних актера. Такође, овим се подсећају потенцијални неистомишљеници колико је висок улог опозиционог деловања. "15 Колико је уплашеност од избијања новог грађанског рата утемељена на сећању и проживљеном у новијој историји, а колико је индукована кроз информативно-пропагандну делатност власти, свакако је отворено питање!? Ипак, треба узети у обзир да је такво мишљење раширено и отуда бледе реакције након различитих потеза власти.

\footnotetext{
${ }^{14}$ Надежда Ермолаева, „В Таджикистане убит мятежный генерал Назарзода“, Российская газета, 2015, https://rg.ru/2015/09/11/nazarzoda-site-anons.html (приступљено 23.02.2021).

${ }^{15}$ Markus Göransson, Nearing the brink? Political instability in Tajikistan, Clingendael Institute, The Hague, 2016, https://www.clingendael.org/pub/2016/nearing_the_brink/ (приступљено 01.03.2021).
} 
Друго, Рахмон је постао апсолутно прихватљив „играч“, па чак у појединим тренуцима и неизбежан савезник свим заинтересованим „екстерним актерима“. 3бог географског положаја Таџикистана, за Русију и Кину било је важно да се грађански рат што пре заврши. Рахмон је у томе помогао наметнувши се као способан лидер који може да управља кризом и брзо је постао важан саговорник за Москву и Пекингу. За САД он такође постаје важан саговорник због авганистанског рата који је избио 2001. године. У спречавању ширења утицаја Ал Каиде из Авганистана ка централноазијским постсовјетским републикама таџикистанске власти имале су важну, можда чак и пресудну улогу. Од стабилности Таџикистана делимично је зависио и успех америчке мисије (у коју се, као што је познато, укључује велики број држава унутар мисије ИСАФ), што је мотивисало Вашингтон не само да сарађује са Рахмоном већ и да врло активно подржава његово одржавање на власти (пошто је то био најсигурнији начин очувања стабилности система у врло напетим и непријатним послератним годинама). Такође, Таџикистан има и значајно место у изградњи логистичке мреже којом су снабдеване трупе ИСАФ на територији Авганистана. ${ }^{16}$ Прагматизам побеђује сваку критику о гушењу људских права и слобода, опозиционе гласове и оптужбе за корупционо деловање.

Донације и различите врсте помоћи (укључујући и кредите) Таџикистану, пре свега усмераване од стране САД и међународних финансијских институција, чине око 6\% бруто друштвеног производа, упркос томе што се писало о различитим аферама везаним за нетранспарентно и ненаменско трошење средстава. Међу најзначајнијим је питање пословања алуминијумског комбината, од чијег обрта зависи, директно или индиректно трећина бруто друштвеног производа земље, а који све спољнотрговинске аранжмане обавља преко офшор компаније регистроване на Британским Девичанским Острвима (производи се продају по једној цени офшор компанији, да би их она даље дистрибуирала по вишој цени партнерима у другим државама!). ${ }^{17}$ Уз то,

${ }^{16}$ Krzysztof Strachota, "Tajikistan on the verge of civil war; ISAF and the USA on the verge of new problems", Ośrodek Studiów Wschodnich, Warszawa, 2010, https://www.osw. waw.pl/en/publikacje/analyses/2010-09-22/tajikistan-verge-civil-war-isaf-and-usa-vergenew-problems (приступљено 20.02.2021).

${ }^{17}$ Sofia Wickeberg, "Overview of corruption and anti-corruption in Tajikistan", Transparency International, U4 Anti - Corruption Resource Center, Paper No. 356, 2013, p. 4. 
значајан део прихода различитим групама представља и учешће у трговини авганистанским наркотицима. Током грађанског рата граница према Авганистану дугачка 1.300 километара остала је „отворена“, што је подстакло повезивање произвођача опијата у једној и дистрибутера у другој држави. Поједине процене су да чак 25\% авганистанских опијата на путу ка руском и источноевропским тржиштима пролази кроз централноазијски ареал, а прва „улазна капија“ у том ланцу је најчешће Таџикистан. ${ }^{18}$ Упркос овом сазнању, даље од декларативних упозорења и констатовања у борби против тога, барем када је реч о међународним организацијама, суштински се није ишло. Опет, показује се да циљ оправдава средства, те да је због ширих геополитичких интереса важније одржавати стабилност Таџикистана под Рахмоном, него отварати непријатне процесе који могу резултирати другачијим исходима.

Ипак, и поред чврстог управљања политичким процесима у земљи и несумњивој подршци споља, не може се рећи да изазови безбедности, па самим тим и стабилности, не постоје. Незадовољство у источном делу државе и даље „тиња“, практично, нити један од набројаних узрока избијања грађанског рата није (делимично или чак уопште) елиминисан. Стање је остало какво је и било, само за разлику од почетка деведесетих година и хаоса у који су утонуле новостворене централноазијске (постсовјетске) државе, данас нема критичне масе која може покренути оружани сукоб, нити политичке организације способне да га координира, док је власт у Душанбеу консолидована. ${ }^{19}$ О спорадичним сукобљавањима мањих група са државним полицијским снагама у овом делу земље често се сазнаје са закашњењем, уз селективно информисање јавности. Последњи сукоб већих размера одиграо се у септембру 2010. године. „Према званичним подацима из Таџикистана, 19. септембра у клисури Комароб у долини Рашт (раније позната као Каратагена и Гарм) дошло је до напада на таџикистанску војну колону,

${ }^{18}$ Girija Prasad Mohanty, "Tajikistan: A Transit Hub of Drugs Smuggling”, SSRN, 2010, pp. 25, (January 17, 2010). Available at SSRN: https://ssrn.com/abstract=1537782 (приступљено 02.03.2021).

Такође, о генези проблема може се више пронаћи у раду: Johan Engvall, “The State under Siege: The Drug Trade and Organised Crime in Tajikistan", Europe-Asia Studies, Vol. 58, No. 6, 2006, pp. 827-854.

${ }^{19}$ Markus Göransson, Nearing the brink? Political instability in Tajikistan, op. cit. 
услед чега су 23 војника погинула, а 25 их је рањено. Одговорност за напад стављена је на бивше теренске команданте из времена грађанског рата: Аловудина Давлатова и Абдула Рахимова уз подршку међународних терориста (према једној верзији, постоји и подршка од бегунаца из затвора у Душанбеу, који су побегли 23. августа ове године). Њихове снаге процењују се на 100 људи. То је био највећи оружани сукоб у региону од грађанског рата у Таџикистану (завршен 1997) и Баткен кризе (напади Исламског покрета Узбекистана са таџикистанске територије на Узбекистан и Киргистан 1999, 2000).“20 Супротно предвиђањима, до распламсавања сукоба није дошло, али је овај догађај још једанпут указао да потенцијал за избијање новог конфликта постоји.

Такође, међу делом популације уочава се јачање радикалног исламског учења, што је подстакло регрутацију за одлазак на авганистанско и сиријско ратиште на ком је завршило око 500 држављана Таџикистана. Њихов повратак у земљу јесте претња безбедности, као и деловање екстремистичких ћелија на територији земље. Посебно забрињавајуће делује што се овим структурама придружио и полицијски генерал Гулмурод Халимов, главнокомандујући Јединице за специјалне операције, претходно обучаван у америчким безбедносним институцијама (учествовао је у програму који је финансирао Стејт департмент, а такође је прошао обуку у чувеној приватној компанији „Блеквотер“). Халимов је пребегао у Исламску државу изниклу на територије Сирије и Ирака 2015. године, а ирански извори су саопштили да је дванаест месеци касније већ постао војни руководилац и министар одбране у том ентитету (након погибије Абу Умара аш-Шишанија). ${ }^{21} \mathrm{y}$ септембру 2017. године руско Министарство одбране саопштило је да је Халимов ликвидиран у североисточној Сирији. ${ }^{22}$ Ово је показатељ да

${ }^{20}$ Krzysztof Strachota, "Tajikistan on the verge of civil war; ISAF and the USA on the verge of new problems", Ośrodek Studiów Wschodnich, Warszawa, 2010, https://www.osw.waw. pl/en/publikacje/analyses/2010-09-22/tajikistan-verge-civil-war-isaf-and-usa-verge-newproblems

${ }^{21}$ Константин Казеев, „СМИ: Гулмурод Халимов стал новым главарем террористической группировки ИГ“, ТАСС, 2016, https://tass.ru/mezhdunarodnaya-panorama/3591982 (приступљено 25.02.2021).

22 Maxim A. Suchkov, "Don't let Islamic State slip the noose in Syria", Al-Monitor, 2017, https://www.al-monitor.com/pulse/originals/2017/09/russia-offensive-syria-islamic-statemoscow-washington.html (приступљено 21.02.2021). 
присталица екстремиста има и на високим позицијама, могуће и способних да покушају преврате у будућности.

Када је реч о текућим процесима, претњу безбедности представља очајна економска ситуација. Око половине бруто друштвеног производа чине дознаке емиграната (најчешће мужеви који раде у Русији и Казахстану, а достављају сваког месеца новац женама и деци који су остали да живе у Таџикистану), што по овом параметру сврстава Таџикистан у сам светски врх. ${ }^{23}$ Према подацима Светске банке чак 83\% домаћинстава у Таџикистану у потпуности или делимично зависи од дознака из иностранства. ${ }^{24}$ Најпре пад рубље, узрокован санкцијама ЕУ и САД према Русији, затим пад цена енергената који доводи до погоршавања економских прилика у Русији и Казахстану, а затим и последице пандемије, кумулативно су утицали не само да се обим дознака смањи, већ и да део таџикистански емиграната остане без посла и буде принуђен да се врати у домовину. ${ }^{25}$ „То подстиче стрепњу због предстојеће социјалне реакције. Ако је одлазак миграната био погодан сигурносни вентил за ослобађање земље од потенцијалних проблема, њихов повратак у великом броју на тржиште рада које није у стању да их апсорбује може наговештавати будућу нестабилност. Иако економски проблеми краткорочно можда неће рађати нестабилност, ако се не реше, можда ће се показати као извор дугорочних социјалних превирања. "26

\section{Закључак: изазови стабилности - стање и перспективе}

Изражене претње унутрашњој стабилности Таџикистана су очајна економска ситуација, коју погоршава текућа коњуктура у глобалној и регионалној економији (на постсовјетском простору, где економску

${ }^{23}$ International Alert, "Changing patterns of labour migration in Tajikistan", Policy Brief, London, 2016, pp. 1-2.

${ }^{24}$ Rustam Babajanov et al., 2014 National Human Development Report - Tajikistan: Access to Resources for Human Development, UNDP, Dushanbe, 2015, pp. 36-47.

${ }^{25}$ Marina Bakanova, Ravshan Sobirzoda et al., Tajikistan:A moderate Slowdown in Economic Growth Coupled with a Sharp Decline in Household Purchasing Power, Tajikistan Economic Update No. 2, World Bank Group, Washington D.C., 2015, pp. 3-4.

${ }^{26}$ Markus Göransson, Nearing the brink? Political instability in Tajikistan, op. cit. 
динамику пре свега детерминишу кретања у руском привредном систему), деловање радикалних исламистичких група кроз функционисање ћелија екстремистичких организација на територији земље и „незалечени“ узроци грађанског сукобљавања из деведесетих година (неравномерност у односу западни делови државе према источним) који се могу у одређеном развоју ситуације поново актуелизовати. Емомали Рахмон се током аутократске владавине дуге скоро три деценије показао способним да одржи релативну стабилност и спречи избијање нових оружаних конфликата. За то је имао и (некада отворену, а некада прећутну) подршку спољних фактора, који су одабрали прагматичан приступ, јер потенцијалну дестабилизацију Таџикистана сагледавају у ширем контексту регионалне безбедности и последичној проблематизацији стања у Авганистану. Отуда и одсуство притисака или конкретних одлука везаних за питања корупције, обрачуна са политичким неистомишљеницима и најразличитијих облика злоупотребе државног апарата. Ипак, због наведених претњи, као и саме природе аутократске власти, а што подразумева упитност изграђености и функционалности институција, отворено је питање колико дуго оваква стабилност може трајати и шта се уопште може догодити након одласка Рахмона са власти. Прагматични приступ, у овом конкретном случају, значи и да се стабилност пројектује краткорочно, у односу на текуће изазове и у складу са тренутним циљевима, а не дугорочно, кроз изградњу институција и јасну визију о месту и улози једне државе у регионалном систему безбедности.

\section{Библиографија}

Babajanov, Rustam, et al., 2014 National Human Development Report Tajikistan: Access to Resources for Human Development, UNDP, Dushanbe, 2015.

Bakanova, Marina, Ravshan, Sobirzoda et al., Tajikistan:A moderate Slowdown in Economic Growth Coupled with a Sharp Decline in Household Purchasing Power, Tajikistan Economic Update No. 2, World Bank Group, Washington D.C., 2015. 
Бушков, В. И., Микульский, Д. В., Анатомия гражданской войны в Таджикистане (этно-социальные процессы и политическая борьба, 1992-1995), Институт этнологии и антропологии РАН: Институт практического востоковедения, Москва, 1996.

Engvall, Johan, "The State under Siege: The Drug Trade and Organised Crime in Tajikistan", Europe-Asia Studies, Vol. 58, No. 6, 2006, pp. 827-854.

Ермолаева, Надежда, „В Таджикистане убит мятежный генерал Назарзода“, Российская газета, 2015, https://rg.ru/2015/09/11/ nazarzoda-site-anons.html

Göransson, Markus, Nearing the brink? Political instability in Tajikistan, Clingendael Institute, The Hague, 2016, https://www.clingendael.org/ pub/2016/nearing_the_brink/

IMF, "World Economic Outlook Database", International Monetary Fund, 2019, https://www.imf.org/en/Publications/SPROLLs/world-economic-outlookdatabases\#sort=\%40imfdate\%20descending

International Alert, "Changing patterns of labour migration in Tajikistan", Policy Brief, London, 2016, pp. 1-3.

Казеев, Константин, „СМИ: Гулмурод Халимов стал новым главарем террористической группировки ИГ“, ТАСС, 2016, https://tass.ru/ mezhdunarodnaya-panorama/3591982

Pannier, Bruce, “Tajikistan's Civil War: A Nightmare The Government Won't Let Its People Forget", Radio Free Europe, 23 June 2017, https://www.rferl.org/ a/qishloq-ovozi-tajikistan-civil-war/28575338.html

Prasad Mohanty, Girija, "Tajikistan: A Transit Hub of Drugs Smuggling", SSRN, 2010, pp. 2-5, https://ssrn.com/abstract=1537782.

Пророковић, Душан, Ера мултиполарности, Службени гласник, Београд, 2018.

Саъдиев, Шукхрат, История таджикского народа, Институт предпринимательства и сервиса, Душанбе, 2012.

Strachota, Krzysztof, Falkowski, Maciej, „Dżihad i Nowa Wielka Gra. Paradoksy zagrożenia wojującym islamem w Azji Centralnej", Ośrodek Studiów Wschodnich, Warszawa, 2010.

Strachota, Krzysztof, "Tajikistan on the verge of civil war; ISAF and the USA on the verge of new problems", Ośrodek Studiów Wschodnich, Warszawa, 
2010, https://www.osw.waw.pl/en/publikacje/analyses/2010-09-22/tajikistan-verge-civil-war-isaf-and-usa-verge-new-problems

Suchkov, Maxim A., "Don't let Islamic State slip the noose in Syria", Al-Monitor, 2017, https://www.al-monitor.com/pulse/originals/2017/09/russia-offensive-syria-islamic-state-moscow-washington.html

Wickeberg, Sofia, "Overview of corruption and anti - corruption in Tajikistan", Transparency International, U4 Anti - Corruption Resource Center, Paper No. 356, 2013.

\section{MAINTAINING STABILITY AND SECURITY THREATS: THE CASE OF TAJIKISTAN}

Abstract: The civil war, which lasted during the 1990s, determined the long-term political processes in Tajikistan. On the one hand, President Ehmomali Rahmon, undoubtedly the most important actor in the process of stabilizing the situation during the post-war period, consolidated his power and became an unavoidable interlocutor for all external security factors in the Central Asian region. On the other hand, the consequences of the war and economic devastation have left implications that are still felt today and that can be a threat to security. This paper consists of four chapters. In addition to the initial introductory chapter and the final concluding one, the second chapter is dedicated to the description of the causes and consequences of the civil war, and the third to the post-war stabilization and the current situation. The paper presents the challenges of stability and threats to the security of Tajikistan, as well as the attitude of the US, Russia and China towards this issue.

Keywords: Tajikistan, Rahmon, Afghan war, civil war. 